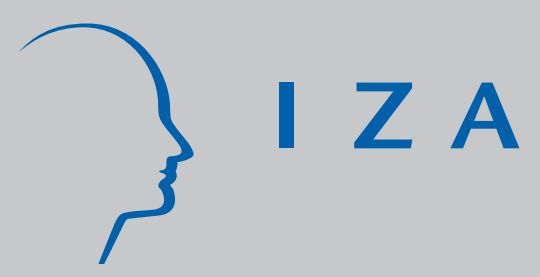

IZADP No. 2410

Poles Apart? EU Enlargement and the Labour Market Outcomes of Immigrants in the UK

Stephen Drinkwater J ohn Eade

Michal Garapich

October 2006 


\title{
Poles Apart? \\ EU Enlargement and the Labour Market Outcomes of Immigrants in the UK
}

\author{
Stephen Drinkwater \\ University of Surrey \\ and IZA Bonn
}

John Eade

University of Surrey

\section{Michal Garapich}

University of Surrey

\section{Discussion Paper No. 2410 \\ October 2006}

\author{
IZA \\ P.O. Box 7240 \\ 53072 Bonn \\ Germany \\ Phone: +49-228-3894-0 \\ Fax: +49-228-3894-180 \\ E-mail: iza@iza.org
}

\begin{abstract}
Any opinions expressed here are those of the author(s) and not those of the institute. Research disseminated by IZA may include views on policy, but the institute itself takes no institutional policy positions.

The Institute for the Study of Labor (IZA) in Bonn is a local and virtual international research center and a place of communication between science, politics and business. IZA is an independent nonprofit company supported by Deutsche Post World Net. The center is associated with the University of Bonn and offers a stimulating research environment through its research networks, research support, and visitors and doctoral programs. IZA engages in (i) original and internationally competitive research in all fields of labor economics, (ii) development of policy concepts, and (iii) dissemination of research results and concepts to the interested public.
\end{abstract}

IZA Discussion Papers often represent preliminary work and are circulated to encourage discussion. Citation of such a paper should account for its provisional character. A revised version may be available directly from the author. 


\section{ABSTRACT}

\section{Poles Apart? EU Enlargement and the Labour Market Outcomes of Immigrants in the UK ${ }^{*}$}

The UK was one of only three countries to allow migrants from accession countries to enter their labour markets more or less without restriction following EU enlargement in May 2004. Therefore, it is important to establish the characteristics and labour market performance of migrants from these countries who have subsequently entered the UK. We principally analyse Labour Force Survey data to compare the labour market outcomes of recent migrants from Poland and other accession countries to those of earlier migrant cohorts from these countries as well as to those of other recent migrants to the UK. We find that the majority of post-enlargement migrants from accession countries have found employment in low paying jobs, despite some (especially Poles) having relatively high levels of education. It follows that recent Polish migrants typically have lower returns to their education than other recent arrivals. Migrants from the new entrants who arrived immediately prior to enlargement possess similar characteristics and labour market outcomes, apart from having a higher propensity to be self-employed. These results are discussed in the context of policy changes, migration strategies, assimilation effects and possible impacts on the sending countries.

JEL Classification: J61, F22

Keywords: migration, EU enlargement, labour market outcomes

Corresponding author:

Stephen Drinkwater

Department of Economics

University of Surrey

Guildford

Surrey GU2 7XH

United Kingdom

E-mail: s.drinkwater@surrey.ac.uk

\footnotetext{
* We are grateful for funding from the Economic and Social Research Council (grant number RES-00022-1294). Material from the Quarterly Labour Force Survey is Crown Copyright and has been made available by the Office for National Statistics through the Data Archive at the University of Essex. We are grateful to comments received from participants at the 2006 Work and Pensions Economics Group Annual Conference at the University of Kent. The views expressed in this work and errors therein are those of the authors.
} 


\section{Introduction}

It has been argued that the enlargement of the EU that took place in May 2004 has produced the largest ever wave of immigration to the UK (Salt and Rees, 2006). This was mainly the outcome of the UK being one of only three existing member states, along with Ireland and Sweden, to allow migrants from accession countries to enter their countries more or less without restriction. Thus, given that enlargement has basically enabled individuals to move from relatively poor accession countries to three prosperous member states, it is important to analyse the migration that has actually taken place to these countries since accession. Not only is the scale of migration important but also the composition of these flows. Therefore, this paper is concerned with population movements from the A8 group of accession countries to the largest of these economies, the UK, and the subsequent performance of these migrants in the UK labour market.

In the analysis that follows we place particular emphasis on examining migration from Poland since this country was by far the biggest of the new entrants as well as possessing a very poorly performing labour market at the time of accession. In particular, the unemployment rate in Poland in 2003 was almost 20\%, which was the highest of all A8 countries, whilst unemployment in the UK was amongst the lowest in the EU, at less than $5 \% .{ }^{1}$ Wages have also been very low in Poland in recent years, for example Sinn (2002) reports that the average hourly wage in the engineering industry was 4.80 Deutsch Marks (DM) in West Poland and 2.70 DM in East Poland, compared to 28.50 DM in Munich. ${ }^{2}$ Furthermore, there has also been a long history of Polish migration to the UK, particularly in the immediate aftermath of the Second

\footnotetext{
${ }^{1}$ Unemployment was also relatively high in Slovakia in 2003, running at slightly over 16\%, whilst unemployment rates of less than $12 \%$ were recorded in the remainder of the A8.

${ }^{2}$ More generally, wages in accession countries were very low at the time of enlargement. Sinn (2004) states that hourly labour costs were less than 5.3 Euro in all A8 countries in 2003, compared to over 27 Euro in West Germany.
} 
World War (Sword, 1996; Zubrzycki 1956), which implies that the mechanisms needed to establish a new migration network may have already been in place. The importance of Polish migration is further demonstrated by the fact that more than $60 \%$ of the new immigrants to the UK from the A8 group of accession countries have come from Poland (Home Office et al., 2006).

The paper proceeds in the following manner. In the next section, there is a discussion of the migration policies adopted by individual member states in the lead up to and following enlargement, with a particular emphasis on the position of the UK. This is followed by an analysis of the volume of migration from A8 countries, as well as some information on the characteristics of migrants using the Worker Registration Scheme. Section 3 contains a more detailed examination of the characteristics and labour market outcomes of immigrants from the new entrants using the Labour Force Survey. In particular, these individuals are compared directly with other recent immigrants from non-accession countries as well as to earlier cohorts of arrivals from the new entrants. The empirical methodology is described in Section 4, followed by a discussion of the econometric results in Section 5. The latter section pays particular attention to the returns to education and it is found that Poles who have arrived in the UK after enlargement experience low returns to their education. Section 6 contains some concluding comments.

\section{EU Enlargement and Immigration from A8 Countries to the UK}

Boeri and Brucker (2005) distinguish four different types of transitional regimes that have been implemented in the EU with respect to migration from the new entrants. Seven member states adopted a restrictive immigration regime which effectively blocked access to their labour markets for at least two years following enlargement, 
with the possibility of extending these arrangements for another five years. A further four countries introduced similar rules but did allow for a quota of migrants from new member states. Denmark, Ireland and the UK allowed migrants from the new member states to enter their labour markets as long as certain requirements were met. ${ }^{3}$ Finally, only Sweden allowed labour to move freely into their country from the accession countries.

Given that this paper focuses only on the UK, it is worth discussing the arrangements implemented in the UK in greater detail. Nationals from two of the new entrants, Cyprus and Malta, were granted full free movement rights and rights to work, whilst transitional measures were applied to nationals from the other eight entrants - subsequently referred to as the A8. In particular, in order to take up employment in the UK, A8 nationals are required to register with the Worker Registration Scheme (WRS). ${ }^{4}$ The access of A8 nationals to the UK labour market is further regulated by the restriction of access to welfare benefits.

In terms of previous migration from the A8 to the UK, there has only really been a history of Polish migration to the UK, especially immediately after the Second World War, with a Polish born population of over 162,000 recorded in 1951 (Sword, 1996). However, Sword (1996) suggests that only relatively small inflows arrived in the UK up until the beginning of the Twenty-First Century and there was even some return migration after the collapse of communism. As a result, the 2001 Census recorded less than 61,000 Polish-born individuals living in the UK, 57\% of whom

\footnotetext{
${ }^{3}$ In Ireland and UK, the migrants have to register for work and residence permits, whilst access to welfare benefits is limited and permits may be withdrawn if the migrant is unemployed. The arrangements in Denmark are more restrictive in that work permits are only issued for one year so it has been argued e.g. by the TUC (2004) and others that there were no restrictions to migration in only three member states: Ireland, Sweden and the UK. In April 2006, four other member states (Finland, Greece, Portugal and Spain) announced that they were lifting the restrictions that they had imposed two years earlier.

${ }^{4}$ Applicants are supposed to register more than once if they have more than one employer and also reregister if they change employer. The cost per registration was initially set at $£ 50$ but has subsequently been raised to $£ 75$.
} 
were aged over 64. Nevertheless, there remains an active Polish diaspora in the UK, which may have encouraged the flow of Poles post-enlargement by providing an established migration network (Sword, 1996; Garapich, 2006). ${ }^{5}$ In contrast, migration from other A8 countries to the UK before 2004 had been pretty limited. For example, there were less than 13,000 Hungarians and 9,000 Czechs and Slovaks resident in Great Britain according to the 1991 Census. $^{6}$

Although $1^{\text {st }}$ May 2004 appeared to liberalize migration from Poland and other A8 countries overnight (and was also a de facto amnesty of undocumented workers), liberalization was in fact much more of a process than this. From the late 1990s, Poles in particular increasingly took advantage of a provision granted by the Europe Agreement of 1991 (ratified in 1994) between the EU and candidate states that allowed migrants to set up their own private businesses. The result was a considerable increase in those entering via the self-employment route. For example, the Home Office (2003) reported that there was a 156\% increase in the number of Poles granted an extension as a person of independent means or as businessmen in 2003, taking the number to 9,410 . The self-employment scheme was much more favourable towards Poles who could apply for it while technically entering UK as tourists, unlike for example Romanians or Bulgarians who needed to apply from their own countries.

Furthermore, although it is virtually impossible to provide an estimate of undocumented migration by Poles prior to 2004, both qualitative and indirect quantitative data (e.g. on persons refused entry, the number of business trips, students, au pairs and tourists) suggests this is likely to have been substantial. In particular,

\footnotetext{
${ }^{5}$ These are mainly composed of Second World War combatants, women joining their families in the 1950s, Polish Jews escaping persecution from the anti-Semitic policies of the communist government after 1968, 'Solidarity' opposition activists trapped by the imposition of Martial Law in 1981 plus their families later in the 1980s.

${ }^{6}$ No breakdown is available for Eastern European countries other than Poland in the 2001 Census. The total number of non-Polish Eastern Europeans in the UK in 2001 was around 187,000.
} 
Duvell (2004) notes "Polish nationals currently have either been identified by the Immigration Service Enforcement Directorate for its illegal strategies or, as most recently by Work Permits UK as a noticeable group. In 1996, Polish nationals came third amongst those being identified for illegal entry" (p. 5). Whilst similar information for 2001-2003 reveals that Poles were by far the most likely national group to be refused entry to the UK in each of these years. Therefore when considering the size of Polish population in the UK, the state of the Polish economy, dynamically developing social networks, migratory social capital, strategies of entries and undocumented activities are important factors (Okolski, 2001; Triandafyllidou, 2006).

It had been predicted that only a small number of migrants would arrive in the UK from the A8 following enlargement. For example, Dustmann et al. (2003) forecast that net migration to the UK from accession countries would be in the range of 5,000 to 13,000 per annum. ${ }^{7}$ However, the actual movements since enlargement have been vastly larger than this. In particular, it can be seen from Table 1, which reports basic information on registrants on the WRS and are taken from the most recent Accession Monitoring Report (Home Office et al., 2006), that more than 427,000 A8 migrants entered the UK up to June 2006. Earlier information from the WRS was analysed by Portes and French (2005), who found that the increased migration from A8 countries had a small, but broadly positive, impact on the UK labour market.

The basic demographic information provided by the WRS indicates that almost 62\% of applications to work in the UK between May 2004 and June 2006 from

\footnotetext{
${ }^{7}$ This analysis did assume though that A8 migrants would be allowed to move freely around the EU post-enlargement since it was predicted that net immigration to Germany would be between 20,000 and 210,000 per year. Further evidence on the migration potential from Eastern Europe and the importance of Germany as a destination for A8 migrants can be found in Sinn and Werding (2001), who projected that between 4 and 5\% of the population of accession countries would migrate to existing member states in the 15 years following May 2004 if immigration was not restricted.
} 
A8 countries came from Poland. Lithuanians and Slovakians each contributed more than $10 \%$ of WRS applications. ${ }^{8}$ The majority of applications up to June 2005 came from individuals who had entered the country post-enlargement (around 82\% of those who gave a date), whilst around 10\% came before 2004 and the remaining $8 \%$ said that they arrived in early $2004 .{ }^{9}$ Although there is a question on the expected duration of stay in the WRS, this information is not reported in the Accession Monitoring Report. However, some indication of the nature of migration from the A8 postaccession can be inferred from examining the volume of applications at different times of the year. It is found that applications (and registrations) have peaked in summer months and are relatively low in the winter - this is partly due to the migration of workers to work in agriculture and tourism related industries in summer months but also due to migrants who have returned to Poland over the winter reregistering on the scheme.

In terms of the characteristics of registered workers, the overwhelming majority are aged between 18 and 34, with less than 18\% aged 35 and over and only a small proportion (just over 7\%) bringing dependants with them. The geographic distribution of A8 migrants appears to be somewhat different to that of previous cohorts of immigrants since less than $14 \%$ have moved to London, compared to the $40 \%$ of all immigrants to the UK according to the 2001 Census. Instead, a higher percentage of A8 migrants have located in Anglia and relatively large numbers in the Midlands and Central. There is a small gender imbalance since 58\% of registered workers are male.

\footnotetext{
${ }^{8}$ Portes and French (2005) report that Lithuanians and Latvians had the highest percentage of emigrants when expressed as a proportion of the home population, with the emigration rate of Lithuanians to the UK being three times higher than that of Poles in the eight months following enlargement.

${ }^{9}$ This information has not been reported in recent Accession Monitoring Reports.
} 
In terms of the types of jobs that A8 migrants have found in the UK, Table 1 reports that over a third of registrants are employed in the business, management and administration sectors and just over a fifth in hospitality and catering. Agriculture is the only other industrial sector which has attracted more than $10 \%$ of registrants. Further information on the nature of jobs taken by A8 migrants can be obtained from occupational data. According to the WRS, around a quarter of registrants are described as process operatives. The remainder of the top 10 most common occupations are also low skilled, although none of these occupations individually accounts for more than $7 \%$ of registrants. This indicates that the occupational distribution of recent A8 migrants is far more dispersed than the industrial distribution. In addition to the relatively high percentage of registrants in other occupations, a large proportion of registrants did not state their occupation. Nevertheless, it appears that recent A8 migrants overwhelmingly work in low paidlow skilled jobs.

\section{Data and Descriptive Statistics}

The data that will subsequently be analysed in this paper are taken from the Labour Force Survey (LFS). This is a representative cross-sectional survey that has been used extensively in examining the labour market outcomes of immigrants in the UK (for example, Blackaby et al., 2005; Dustmann and Fabbri, 2005; Dustmann and Theodoropoulos, 2006; Shields and Wheatley Price, 1998). The LFS is conducted on a quarterly basis and aims to obtain a sample of around 60,000 households every quarter. LFS respondents are interviewed in five successive waves, thus approximately a fifth of the sample in each quarter will contain individuals from each of the five waves. Therefore, to avoid possible double counting, only individuals who 
are in their first wave of interviews are selected. This is done because respondents are only asked earnings questions in this wave (as well as in wave 5) and there is likely to be less attrition bias given that A8 immigrants may only stay in the country for a short amount of time.

Given that the LFS only samples a relatively small proportion of the population, there are only fairly low numbers of recent A8 migrants in the data, despite the large numbers identified by the WRS. Nevertheless, the LFS is the main dataset to be analysed in this paper since unlike the LFS, the WRS only contains very basic range on other characteristics. Furthermore, it is possible to compare the performance of A8 immigrants to other groups of post-enlargement migrants to the UK as well as to earlier cohorts of migrants from A8 countries using the LFS.

To obtain sufficient observations on the different migrant groups, the dataset covers the period from Autumn 2001 to Summer 2006, which was the most recent quarter available at the time of writing. However, given that EU enlargement only took place in May 2004, this only leaves around 9 quarters when post-enlargement migrants are available for analysis, which restricts the sample available. For example, Table 2 reports that there are only 259 Polish migrants of working age in the sample who arrived in the UK post-May 2004, despite this group accounting for $17 \%$ of all working age migrants to the UK over this period according to LFS. ${ }^{10}$ Nevertheless, statistics for this group are reported in addition to those for other post-enlargement migrants from A8 countries as well as from three other groups - other European countries, English speaking countries and other countries. ${ }^{11}$ Two other cohorts of the Polish-born and immigrants from other A8 countries are also included for

\footnotetext{
${ }^{10}$ Similarly, there are only 179 other A8 migrants although this group represents more than $10 \%$ of working age immigrants entering the UK after May 2004.

${ }^{11}$ English speaking countries includes the United States, Canada, Australia, New Zealand and South Africa. This group is separately identified because of the large language penalties that have been found for immigrants in the UK labour market (Dustmann and Fabbri, 2003; Leslie and Lindley, 2001).
} 
comparative purposes. These two cohorts are those arriving from 2000 to 2003 i.e. immediately prior to enlargement and those who entered before 2000.

It can be seen from Table 2 that the characteristics of recent Polish and A8 migrants in the LFS are similar to those reported in the WRS. In particular, migrants are overwhelmingly in the 16-35 age category, there is an over-representation of males (especially among Poles), under $40 \%$ are married and a relatively small percentage have located in London and its surrounding areas. The characteristics of Polish and other A8 migrants arriving just prior to enlargement is fairly similar, although there is a higher proportion of females and a greater tendency to live in London and the East/South East. Other recent migrants are also more likely to reside in London and its surrounds, especially those from English speaking countries and the three other migrant groups arriving after enlargement all had a higher proportion of females. Recent Other European migrants are less likely to be married, whilst the opposite is true of migrants from other countries.

Before examining labour market outcomes, it is important to discuss how one of the key determinants of these variables, namely education, is defined in our study. Unfortunately, there is only limited information on highest qualification attained given that the majority of immigrants in the sample, especially from the A8, obtained all of their education outside of the UK. This is because overseas qualifications do not map into the UK qualifications specified in the LFS very closely, with the result that most overseas qualifications fall into the 'other' category. However, the majority of immigrants do answer the age left full-time education question, which allows a years of education variable to be defined. One issue with creating such a variable is that the age that children start full-time schooling varies by country. To take account of this, we follow the approach used by Dustmann and Theodoropoulos (2006). They subtract 
the age that children begin full-time education in their home country, using the World Bank's education statistics, from the age that the migrant left full-time education. It can seen from Table 2 that the age left full-time education is relatively high amongst recent Polish migrants but is much lower for recent migrants from Other A8 countries. This partly reflects the fact that some migrant groups, including recent A8 migrants, have relatively high proportions of students, who have yet to complete their full-time education. However, this finding also implies that recent Polish migrants are not typically the most low skilled. Further evidence of this can be found by comparing with earlier cohorts of Polish migrants, who left education at a very similar age.

Labour market statistics for each of these groups, excluding full-time students, are reported in the bottom panel of Table 2. It can be seen that Poles have the highest employment rates for those arriving post-enlargement, followed by migrants from English speaking countries. For both of these groups more than three-quarters of individuals entering the UK after 2003 were employed at the time of their interviews. Employment rates are far lower amongst the other three groups of recent migrants. Some of these differences are due to inactivity amongst females, especially among migrants from other countries, but there also appears to be relatively high levels of unemployment and sickness amongst Other A8 migrants. There are also some interesting differences in terms of self-employment. Although it is not unexpected that recent immigrants will have very low rates of self-employment, which is the case amongst all five groups, because it is likely that these groups will have difficulty obtaining the capital required to start a business (Borjas, 1986), there are much higher self-employment rates of A8 migrants arriving shortly before enlargement. This is especially true of Poles, since roughly a third of this group with jobs who arrived between 2000 and 2003 are self-employed. A likely explanation for this is the scheme 
described in Section 2, which allowed self-employed migrants from A8 countries to enter the UK before enlargement. The self-employment rate amongst Other A8 migrants arriving between 2000 and 2003 is much lower though since it is just over $15 \%$.

In terms of the employment variables, recent immigrants are mainly employed in the service sector. This is less pronounced for other A8 immigrants, who have quite high proportions employed in production industries. ${ }^{12}$ Almost $30 \%$ of Polish recent immigrants are employed in hospitality (retail/hotels/catering), which is by far the highest of any of the recent immigrant groups. The relatively high proportion of Poles arriving between 2000 and 2003 who are employed in construction reflects the high concentration of self-employed in this sector i.e. the Polish builder phenomenon. In terms of occupation, post-enlargement A8 migrants have mainly found employment in semi-routine and routine occupations. For example, around three-quarters of Poles and Other A8 migrants have semi-routine and routine occupations. This situation contrasts sharply with other recent immigrants to the UK, where 68\% from English speaking countries and $42 \%$ of other Europeans have professional/managerial jobs, compared to less than $10 \%$ from A8 countries. A relatively large proportion from earlier cohorts of A8 migrants also have high or intermediate occupations, although there is a low percentage of managers and professionals amongst A8 migrants arriving between 2000 and 2003.

The educational differences identified earlier are largely preserved for those in employment, with recent Polish migrants having similar levels of education to other migrants entering the UK after 2003 and much lower levels of education amongst Other A8 migrants. Average earnings are just over $£ 6$ an hour for recent Polish and

\footnotetext{
${ }^{12}$ This is consistent with occupational data from WRS, although the sample size for this group is quite small. This category includes agriculture, energy and manufacturing.
} 
Other A8 immigrants, which is consistent with information in the WRS (Portes and French, 2005; Home Office et al., 2006) and in the large survey conducted by Anderson et al. (2006), who report that the average earnings of recent migrants from Central and Eastern Europe were £5.94. These earnings figures only just exceed the national minimum wage, which was set at $£ 4.50$ in May 2004 and had risen to $£ 5.05$ by June $2006 .^{13}$ This is much less than the earnings of post-enlargement migrants from other countries and well under half as much as those from English speaking countries. Poles and Other A8 migrants arriving prior to 2000 also earn in excess of $£ 11$ an hour but the earnings of A8 immigrants arriving earlier in this decade is only slightly higher than those arriving post-enlargement. There are not large differences in terms of hours of work amongst the migrant groups but recent arrivals from English speaking countries and Poland work the longest hours. ${ }^{14}$ Therefore, it appears that Poles do work slightly longer hours to make up for their lower hourly earnings.

\section{Empirical Methodology}

The empirical strategy is based on analysing the relative earnings of recent Polish and Other A8 migrants using three separate approaches. Earnings are focused upon because of the large differentials identified in Section 3 and the WRS indicates that very few post-enlargement migrants have claimed benefits. ${ }^{15}$ In the first approach, the earnings of post-enlargement Polish and Other A8 migrants are compared to those of other migrant groups entering the UK since 2004. In the second, the earnings of recent

\footnotetext{
${ }^{13}$ Portes and French (2005) report that more than 80\% of A8 immigrants registered on the WRS earned between $£ 4.50$ and $£ 6$ and hour. Earnings data are reported in May 2004 prices.

${ }^{14}$ This measures total hours in the worker's first and second jobs, although less than $4 \%$ held second jobs.

${ }^{15}$ There have been only 1,777 applications for income support, 4,083 applications for Jobseeker's Allowance and 83 applications for State Pension Credit between May 2004 and June 2006 according to Home Office et al. (2006). Only $13 \%$ of total applications were allowed to proceed to further processing. However, from the previous section it appears that the employment rate amongst Other A8 migrants is relatively low.
} 
Polish and Other A8 migrants are compared to those of earlier cohorts of migrants from these countries. Whilst in the third approach, cohort dummies are replaced with a continuous measure of time of arrival and the performance of migrants from A8 countries is compared with the other migrant groups. The first approach is followed because of the need to compare immigrants from different countries arriving around the same time, given the influence that labour market conditions at the time of arrival can have on individual outcomes (Chiswick et al., 1997). The second and third approaches are taken because the importance of cohort and assimilation effects has been recognised since the seminal work of Borjas (1985). By comparing with earlier arrivals from the same countries of origin, this should reduce problems associated with the heterogeneity of different groups of immigrants.

Therefore, the first set of equations to be estimated is based around the model shown in equation (1):

$$
\log w_{i}=\alpha+\sum_{j=1}^{4} \delta_{j} D_{j i}+X_{i}^{\prime} \beta+\varepsilon_{i}
$$

where $w_{i}$ is the wage of individual $i, \alpha$ is a constant term, $X_{i}$ is a vector of personal and job-related characteristics and $\varepsilon_{i}$ is an error term. $D_{j i}$ contains a set of 4 migrant dummy variables (including controls for Poles and Other A8 migrants and is measured relative to Other Europeans) and $\delta_{j}$ their associated coefficients. ${ }^{16} \beta$ is a vector of coefficients to be estimated. This model is only estimated for migrants arriving in the UK in 2004 or after.

\footnotetext{
${ }^{16}$ The adjusted percentage wage differential (relative to Other Europeans) can be calculated by substituting the estimated coefficient for migrant group $j\left(\hat{\delta}_{j}\right)$ into the following formula $\left\{\left[\exp \left(\hat{\delta}_{j}\right)-1\right] \times 100\right\}$.
} 
The second set of equations to be estimated is based around the model shown in equation (2):

$$
\log w_{i}=\alpha+\sum_{j=1}^{4} \phi_{j} C_{j i}+X_{i}^{\prime} \beta+\varepsilon_{i}
$$

where $C_{j i}$ contains a set of 4 cohort dummies (measured relative to compatriots arriving prior to 1980) and $\phi_{j}$ their associated coefficients, whilst the other terms are as above. This model is estimated separately for all Polish migrants and those originating from Other A8 countries. Means for the explanatory variables in the models estimated for recent migrants, Poles and Other A8 migrants are reported in Table A1.

Finally, a set of equations are estimated for the five immigrant groups that include a continuous measure of the time since the migrant entered the UK:

$$
\log w_{i}=\alpha+\gamma Y S M_{i}+X_{i}^{\prime} \beta+\varepsilon_{i}
$$

where YSM is the number of years since the individual $i$ arrived in the UK and $\gamma$ its estimated coefficient. These models are estimated with and without a term which interacts the years since migration variable with years of education. This is done to indicate how the rate of return to education varies for each migrant group according to their time of arrival in order to establish whether recent arrivals from A8 countries have received lower returns to their education compared to earlier arrivals/other migrant groups.

\section{Results}

Table 3 presents the results from estimating equation (1), whilst the results from estimating equation (2) for Polish and Other A8 migrants are contained in Tables 4 and 5 respectively. Each table reports four specifications. The first is a basic 
Mincerian wage equation augmented by the migrant group/cohort dummies, to which are added basic personal and job-related characteristics in the second and third specifications respectively. Specification 4 adds occupational dummies to specification 3.

Table 3 reveals that there exist very large wage differences between the different groups of post-enlargement migrants within a basic Mincerian framework. For example, Polish and Other A8 migrants earn respectively 28\% and 32\% less than European migrants who arrived post-2003 after human capital differences have been controlled for. The earnings of migrants from the rest of the world are just under $20 \%$ lower than those entering from other European countries, whilst those from English speaking countries earn 30\% more. These differences only narrow slightly when basic demographic characteristics are included. Not only does the fit of the model increase quite markedly once job-related factors are added but the earnings differentials are also reduced. Controlling for industry and other employment characteristics reduces the earnings differentials relative to Other Europeans to $21 \%$ and $28 \%$ respectively for recent Polish and other A8 migrants. ${ }^{17}$ The importance of occupation on earnings is demonstrated by the further reduction of the differentials to $13 \%$ and $21 \%$ respectively. Furthermore, the earnings differential for Poles becomes equal to that of migrants from the rest of the world and no longer significantly different from Other Europeans at the 1 per cent level.

Tables 4 and 5 indicate that recent Other A8 migrants have lower earnings relative to earlier cohorts from these countries in comparison to their Polish counterparts. For example, using specification 1, Other A8 migrants arriving after 2003 earn around 45\% less than those arriving before 1980, after controlling for

\footnotetext{
${ }^{17}$ There are no controls for union status because the questions on unions are only asked in the Spring quarter of the LFS.
} 
human capital differences, whilst the equivalent differential is around 37\% for Poles. Very similar pay differentials are observed for Polish and Other A8 migrants arriving between 2000 and 2003 to those arriving after enlargement. Poles arriving in the 1980s also experience a large earnings deficit compared to those arriving before 1980 . However, the earnings functions for Poles and Other A8 migrants are very similar in that an extra year of education increases earnings by between 6 and $7 \%$ for both groups and the first year of experience adds around 2\% to earnings. The percentage wage differentials are higher in specification 2, increasing to $42 \%$ and $60 \%$ for recent migrants from Poland and Other A8 countries respectively. This is due to the much higher percentage of males and the different settlement patterns among recent arrivals from these countries compared to earlier cohorts. Again the value of R-squared increases substantially when the job-related characteristics are included and the earnings differentials are reduced considerably for post-enlargement migrants compared to earlier arrivals. For example, Poles arriving after enlargement earn 20\% less than compatriots who arrived before 1980, whilst the equivalent differential for Other A8 migrants is $27 \%$. Adding occupational controls only slightly narrows the earnings differential for Poles, whereas it has a much larger effect for migrants from Other A8 countries, lowering the differential to $18 \%$.

Table 6, which reports the results of estimating equation (3) for the five migrant groups, reveals that returns to both education and experience are lowest for Polish migrants using specification 1 . The return to education is similarly low for migrants from other A8 countries when only human capital and personal characteristics are included but rises in relative terms when job-related characteristics are added. The effect of years since migration is also high for migrants from A8 countries, especially for non-Poles. This variable is significantly different from zero at 
the $1 \%$ level for both categories of A8 migrants in specification 1 . However, the influence of cohort effects is substantially reduced when the job-related characteristics are included, with the result that this variable is no longer significant. This again indicates the importance of occupation for recent A8 migrants.

The lower portion of Table 6 reports the estimates from the specifications that include a term which interacts years since migration with years of education. The sign on the interaction term is only positive for Poles and migrants from other countries in the models that only control for human capital and personal characteristics. Although the magnitude of this effect is relatively large for Poles, especially compared to Other A8 migrants, it is not significant at commonly used levels. Nevertheless, it reinforces what the descriptive statistics presented in Section 3 showed, in that recently arrived Poles are primarily employed in low paying jobs despite possessing reasonably high levels of education. Again the impact of years of education, as well as the interaction term, is reduced when job-related factors are added.

\section{Conclusion}

The Worker Registration Scheme has shown that there has been a huge influx of A8 migrants to the UK since EU enlargement. However until now, relatively little has been known about the characteristics of these migrants, as well as their performance in the labour market. This paper has demonstrated that although some recent migrants from A8 countries are low skilled, many have relatively high levels of education despite the majority being employed in very low paying jobs. This is especially true of Poles, which means that these individuals typically have lower rates of return to their human capital than other recent migrants, even after controlling for other personal and job-related characteristics. 
This analysis raises a number of issues. For example, are these individuals planning to stay in the UK for long periods or has enlargement produced a guestworker type of system, dominated by temporary migration? At present, little is known about the nature of migration but qualitative evidence on the expected duration of stay, such as by Eade and Garapich (2006), suggests that many recent Polish migrants are unsure of how long they will stay but that a fairly high proportion expect to work in the UK for relatively long periods. If this is the case then it will be interesting to observe how well these workers progress in the UK labour market. In particular, will these individuals experience the similar levels of assimilation as previous cohorts? Furthermore, are the low paid positions currently being filled by such migrants just entry level jobs given that many have reasonably high levels of education or will they remain stuck in these jobs for long periods? The availability of more detailed data should provide clearer insights on these issues.

The fact that it is not just low skilled migrants who have left Poland for the UK since the borders have opened accords with evidence presented by Chiquiar and Hanson (2005) for Mexican migration to the US. They find that Mexican migrants to the US have intermediate rather than low skills, which contrasts with the view of Borjas (1987), who argues that migrants from poor countries should be negatively selected in that migrants from poor countries tend to be lower skilled. In theoretical terms, Chiquiar and Hanson (2005) argue that the financial costs of migration are not constant across individuals and these may deter some low skilled individuals from migrating in spite of the potentially high returns on offer. The reasoning of Chiquiar and Hanson (2005) is further strengthened by the presence of psychic and search costs, which are likely to be more easily overcome by individuals with higher levels of education. 
Finally, although most recent A8 migrants have found low paying jobs in the UK, there are a number of possible benefits to these migration flows since migrants are likely to take the skills and savings they have acquired in the UK back to their home countries, as well as sending back remittances. These issues are particularly important in the context of Poland given the poor recent performance of that economy. In particular, Caselli and Tenreyo (2005) argue that a reallocation from agriculture to higher value sectors and physical capital deepening are required in order for the Poland to catch up in productivity terms with other parts of the EU. Therefore, investment of remittances and repatriated savings into high value sectors could greatly aid this process. Further research on the volume of remittances and savings flowing back to the new member states and what uses these funds are put to is therefore another important avenue for future research. 


\section{References}

Anderson, B., Ruhs, M., Rogaly, B. and Spencer, S. (2006), Fair Enough? Central and Eastern European Migrants in the Low-Wage Employment in the UK, COMPAS Research Report, University of Oxford.

Borjas, G. (1985), "Assimilation, changes in cohort quality, and the earnings of immigrants”, Journal of Labor Economics, 3, 463-489.

Borjas, G. (1986), "The self-employment experience of immigrants”, Journal of Human Resources, 21, 485-506.

Borjas, G. (1987), "Self-selection and the earnings of immigrants", American Economic Review, 77, 531-553.

Blackaby, D. H., Leslie, D. G., Murphy, P. D. and O’Leary, N. C. (2005), "Born in Britain: How are native ethnic minorities faring in the British labour market?", Economics Letters, 88, 370-375.

Boeri, T. and Brucker, H. (2005), "Why are Europeans so tough on migrants?", Economic Policy, October, 630-703.

Caselli, F. and Tenreyro, S. (2005), "Is Poland the next Spain?”, NBER Working Paper No. 11045.

Chiquiar, D. and Hanson, G. (2005), "International migration, self-selection, and the distribution of wages: Evidence from Mexico and the United States”, Journal of Political Economy, 113, 239-281

Chiswick, B., Cohen, Y. and Zach, T. (1997), “The labor market status of immigrants: Effects of the unemployment rate at arrival and duration of residence", Industrial and Labor Relations Review, 50, 289-303.

Dustmann, C., Casanove, M., Fertig, M., Preston, I. and Schmidt, C. (2003), The Impact of EU Enlargement on Migration Flows, Home Office Online Report No. 25/03.

Dustmann, C. and Fabbri, F. (2003), "Language proficiency and labour market performance of immigrants in the UK”, Economic Journal, 113, 695-717.

Dustmann, C. and Fabbri, F. (2005), “Immigrants in the British labour market”, Fiscal Studies, 26, 423-470.

Dustmann, C. and Theodoropoulos, N. (2006), "Ethnic minority immigrants and their children in Britain”, mimeo, Centre for Research and Analysis of Migration, University College London.

Duvell, F. (2004), "Polish undocumented immigrants, regular high-skilled workers and entrepreneurs in the UK”, Institute for Social Studies Working Paper No. 54, Warsaw University. 
Eade, J. and Garapich, M. (2006), “Researching class and ethnicity: London's new Poles”, mimeo, CRONEM, University of Surrey.

Garapich M. (2006), "My nie mamy z tym nic wspólnego. Polska diaspora na skrzyżowaniu między lokalizmem a globalizacją”, Przegląd Polonijny, Spring, 1.

Home Office (2003), Control of Immigration: Statistics United Kingdom 2003, Home Office, London.

Home Office et al. (2006), Accession Monitoring Report May 2004-June 2006, A joint online report by the Home Office, the Department for Work and Pensions, the HM Revenue \& Customs and the Office of the Deputy Prime Minister.

Leslie, D. and Lindley, J. (2001), “The impact of language ability on employment and earnings of Britain's ethnic communities”, Economica, 68, 587-606.

Okolski M. J. (2001), Ludzie na hustawce. Migracje miedzy peryferiami Polski i Zachodu, Scholar, Warsaw.

Portes, J. and French, S. (2005), "The impact of free movement of workers from central and eastern Europe: Early evidence”, Department of Work and Pensions Working Paper No. 18.

Salt, J. and Rees, P. (2006), "Globalisation, population mobility and impact of migration on population”, ESRC Public Policy Seminar Series.

Shields, M. and Wheatley Price, S. (1998), "The earnings of male immigrants in England: Evidence from the QLFS”, Applied Economics, 30, 1157-1168.

Sinn, H.-W. (2002), "EU enlargement and the future of the welfare state", Scottish Journal of Political Economy, 49, 104-115.

Sinn, H.-W. (2004), "EU enlargement, migration and the new constitution”, CESifo Working Paper No. 1367.

Sinn, H.-W. and Werding, M. (2001), "Immigration following Eastern enlargement”, CESifo Forum, 2, 40-47.

Sword, K. (1996), Identity in Flux: The Polish Community in Britain, School of Slavonic and East European Studies, SSEES Occasional Papers No. 36, University of London.

Triandafyllidou, A. (2006), Contemporary Polish Migration in Europe: The Insiders' Voice, Edwin Mellen Press, Washington DC.

TUC (2004), Migrant Workers from the New Europe, Trade Unions Congress, London.

Zubrzycki, J. (1956), Polish Immigrants in Britain: A Study of Adjustment, Martinus Nijhoff, The Hague. 
Table 1

Characteristics of Individuals on the Workers' Registration Scheme, May 2004-June 2006

\begin{tabular}{|c|c|c|c|c|c|c|c|c|c|}
\hline Country of origin & $\%$ & Age & $\%$ & Region & $\%$ & Sector & $\%$ & Occupation & $\%$ \\
\hline Czech Republic & 5.28 & Under 18 & 0.29 & Anglia & 15.21 & Admin, Bus \& Mgmt & 33.67 & Process operative & 24.69 \\
\hline Estonia & 1.20 & $18-24$ & 42.91 & London & 13.72 & Hospitality \& Cat. & 21.02 & Warehouse operative & 6.49 \\
\hline Hungary & 3.01 & $25-34$ & 39.25 & Midlands & 12.03 & Agriculture & 11.76 & Packer & 6.21 \\
\hline Latvia & 6.26 & $35-44$ & 10.47 & Central & 10.41 & Manufacturing & 7.41 & Kitchen assistant & 6.20 \\
\hline Lithuania & 11.83 & $45-54$ & 6.12 & North East & 9.54 & Food/Fish/Meat Proc. & 5.01 & Cleaner/domestic staff & 5.26 \\
\hline Poland & 61.94 & $55-64$ & 0.80 & South West & 8.71 & Health and Medical & 5.01 & Farm worker & 4.66 \\
\hline Slovak Republic & 10.37 & 65 and over & 0.01 & North West & 8.56 & Retail & 4.23 & Waiter, waitress & 4.08 \\
\hline \multirow[t]{5}{*}{ Slovakia } & 0.10 & Unknown & 0.16 & Scotland & 7.52 & Construction \& Land & 3.90 & Maid/room attendant & 3.56 \\
\hline & & & & South East & 7.18 & Transport & 2.84 & Care assistants & 3.25 \\
\hline & & & & Northern Ireland & 3.84 & Ent. \& Lesiure & 1.72 & Sales assistants & 2.71 \\
\hline & & & & Wales & 2.52 & Education \& Cultural & 1.02 & Labourer, building & 2.71 \\
\hline & & & & Not Stated & 0.74 & Other/Not Stated & 2.40 & Other/Not stated & 30.16 \\
\hline Total & & & & 427,095 & & & & & 388,265 \\
\hline
\end{tabular}


Table 2

Socio-Economic Characteristics of Working Age Immigrants by Cohort of Arrival in the LFS: 2001-2006

\begin{tabular}{|c|c|c|c|c|c|c|c|c|c|}
\hline & \multicolumn{3}{|c|}{ Poles } & \multicolumn{3}{|c|}{ Other A8 Migrants } & \multicolumn{3}{|c|}{ Other Post Enlargement Immigrants } \\
\hline & $\begin{array}{c}\text { Pre } \\
2000 \\
\end{array}$ & 2000-3 & $\begin{array}{l}\text { Post } \\
\text { Enl. }\end{array}$ & $\begin{array}{c}\text { Pre } \\
2000 \\
\end{array}$ & $2000-3$ & $\begin{array}{l}\text { Post } \\
\text { Enl. }\end{array}$ & $\begin{array}{c}\text { Other } \\
\text { European }\end{array}$ & $\begin{array}{l}\text { Eng. Sp. } \\
\text { Countries }\end{array}$ & Other \\
\hline \multicolumn{10}{|l|}{ Demographic Characteristics } \\
\hline \% Male & 36.3 & 48.5 & 61.4 & 35.8 & 37.9 & 53.5 & 49.8 & 48.1 & 46.2 \\
\hline$\%$ aged $16-25$ & 5.1 & 33.1 & 42.9 & 17.4 & 44.4 & 47.1 & 37.6 & 33.3 & 36.9 \\
\hline$\%$ aged $26-35$ & 30.3 & 51.5 & 42.5 & 39.3 & 37.3 & 28.0 & 42.9 & 45.0 & 40.5 \\
\hline$\%$ aged $36-59 / 64$ & 64.5 & 15.4 & 14.7 & 43.3 & 18.3 & 24.8 & 19.5 & 21.7 & 22.6 \\
\hline$\%$ Married & 69.2 & 40.8 & 38.6 & 70.2 & 36.7 & 36.9 & 26.5 & 46.3 & 57.8 \\
\hline \% living in London & 58.1 & 59.2 & 18.9 & 44.8 & 47.9 & 22.9 & 27.5 & 48.9 & 31.6 \\
\hline \% living in East/South East & 18.4 & 18.3 & 19.3 & 23.9 & 23.7 & 12.1 & 26.8 & 24.7 & 20.6 \\
\hline \% living elsewhere in UK & 23.5 & 22.5 & 61.8 & 31.3 & 28.4 & 65.0 & 45.6 & 26.4 & 47.8 \\
\hline Average age left FT education & 20.5 & 20.5 & 20.6 & 19.4 & 19.3 & 18.6 & 20.7 & 20.2 & 19.9 \\
\hline \multicolumn{10}{|c|}{ Employment Variables (excludes full-time students) } \\
\hline Employment Rate & 69.5 & 76.0 & 82.1 & 60.7 & 77.9 & 66.0 & 71.0 & 77.6 & 49.1 \\
\hline Self-employment Rate & 26.5 & 32.4 & 3.5 & 18.7 & 15.1 & 3.0 & 8.0 & 9.0 & 3.5 \\
\hline$\%$ in Production industries & 16.9 & 6.3 & 24.8 & 14.8 & 21.0 & 30.6 & 22.7 & 11.3 & 18.0 \\
\hline$\%$ in Construction industries & 13.0 & 25.2 & 7.4 & 10.2 & 14.3 & 9.2 & 4.0 & 6.9 & 2.1 \\
\hline \% in Retail/hospitality industries & 24.0 & 23.4 & 29.2 & 18.5 & 16.8 & 21.4 & 20.7 & 14.4 & 20.1 \\
\hline$\%$ in Other Services & 46.1 & 45.1 & 38.6 & 56.5 & 47.9 & 38.8 & 52.7 & 67.5 & 59.8 \\
\hline \% Managerial/Professional & 34.8 & 9.0 & 10.4 & 37.4 & 9.2 & 7.1 & 42.4 & 68.3 & 37.1 \\
\hline$\%$ in Intermediate occupations & 39.4 & 43.2 & 14.9 & 40.2 & 27.7 & 15.3 & 23.2 & 14.6 & 16.8 \\
\hline \% in Semi-routine occupations & 14.2 & 19.8 & 33.2 & 12.2 & 17.7 & 24.5 & 15.9 & 9.8 & 25.4 \\
\hline \% in Routine occupations & 11.6 & 27.9 & 41.6 & 10.3 & 45.4 & 53.1 & 18.5 & 7.3 & 20.7 \\
\hline Average years of education & 13.4 & 13.4 & 13.6 & 12.7 & 12.8 & 11.9 & 14.2 & 14.2 & 13.6 \\
\hline Average hours of work & 37.3 & 40.0 & 41.9 & 37.0 & 36.4 & 39.9 & 38.9 & 42.6 & 37.5 \\
\hline Average earnings & 11.45 & 6.32 & 6.03 & 11.25 & 6.60 & 6.07 & 10.52 & 13.96 & 8.26 \\
\hline Sample Size & 234 & 169 & 259 & 201 & 169 & 157 & 287 & 231 & 623 \\
\hline
\end{tabular}


Table 3

Earnings Equations for Post-Enlargement Migrants to the UK

\begin{tabular}{lcccc}
\hline & $\mathbf{1}$ & $\mathbf{2}$ & $\mathbf{3}$ & $\mathbf{4}$ \\
\hline Years of education & $0.069(0.007)$ & $0.062(0.008)$ & $0.037(0.007)$ & $0.017(0.017)$ \\
Experience & $0.027(0.008)$ & $0.021(0.007)$ & $0.012(0.006)$ & $0.008(0.006)$ \\
Experience-squared/100 & $-0.055(0.021)$ & $-0.042(0.020)$ & $-0.028(0.015)$ & $-0.017(0.014)$ \\
Polish & $-0.335(0.064)$ & $-0.317(0.070)$ & $-0.237(0.064)$ & $-0.142(0.059)$ \\
Other A8 & $-0.393(0.093)$ & $-0.378(0.098)$ & $-0.326(0.089)$ & $-0.235(0.090)$ \\
Eng. Speaking Countries & $0.264(0.077)$ & $0.230(0.077)$ & $0.170(0.065)$ & $0.070(0.061)$ \\
Other & $-0.216(0.069)$ & $-0.239(0.072)$ & $-0.176(0.070)$ & $-0.141(0.059)$ \\
\hline Controls for: & & & & \\
Gender & $\mathrm{N}$ & $\mathrm{Y}$ & $\mathrm{Y}$ & $\mathrm{Y}$ \\
Marital Status & $\mathrm{N}$ & $\mathrm{Y}$ & $\mathrm{Y}$ & $\mathrm{Y}$ \\
Region & $\mathrm{N}$ & $\mathrm{Y}$ & $\mathrm{Y}$ & $\mathrm{Y}$ \\
Industry & $\mathrm{N}$ & $\mathrm{N}$ & $\mathrm{Y}$ & $\mathrm{Y}$ \\
Part-time & $\mathrm{N}$ & $\mathrm{N}$ & $\mathrm{Y}$ & $\mathrm{Y}$ \\
Firm size & $\mathrm{N}$ & $\mathrm{N}$ & $\mathrm{Y}$ & $\mathrm{Y}$ \\
Sector (public/private) & $\mathrm{N}$ & $\mathrm{N}$ & $\mathrm{Y}$ & $\mathrm{Y}$ \\
Occupation & $\mathrm{N}$ & $\mathrm{N}$ & $\mathrm{N}$ & 0.629 \\
\hline $\mathrm{R}^{2}$ & 0.320 & 0.374 & 564 & 550 \\
\hline Sample Size & 564 & & 528 \\
\hline \hline
\end{tabular}

Notes: Heteroscedasticity robust standard errors in parentheses. Sample consists of employees of working age and excludes full-time students. The models include 3 marital status, 12 regional, 12 industrial, 3 firm size and 9 occupational dummies. 
Table 4

Earnings Equations for Polish Migrants to the UK

\begin{tabular}{lcccc}
\hline \hline & $\mathbf{1}$ & $\mathbf{2}$ & $\mathbf{3}$ & $\mathbf{4}$ \\
\hline Years of education & $0.064(0.011)$ & $0.063(0.012)$ & $0.047(0.012)$ & $0.032(0.013)$ \\
Experience & $0.023(0.012)$ & $0.018(0.014)$ & $0.009(0.010)$ & $0.017(0.009)$ \\
Experience-squared/100 & $-0.052(0.037)$ & $-0.043(0.039)$ & $-0.028(0.030)$ & $-0.049(0.027)$ \\
$1980 s$ & $-0.435(0.206)$ & $-0.477(0.211)$ & $-0.357(0.210)$ & $-0.383(0.186)$ \\
$1990 s$ & $-0.058(0.203)$ & $-0.136(0.209)$ & $0.009(0.206)$ & $-0.056(0.221)$ \\
2000-3 & $-0.445(0.210)$ & $-0.558(0.222)$ & $-0.264(0.186)$ & $-0.228(0.181)$ \\
Post-Enlargement & $-0.456(0.196)$ & $-0.537(0.205)$ & $-0.228(0.177)$ & $-0.204(0.171)$ \\
\hline Controls for: & & & & \\
Gender & $\mathrm{N}$ & $\mathrm{Y}$ & $\mathrm{Y}$ & $\mathrm{Y}$ \\
Marital Status & $\mathrm{N}$ & $\mathrm{Y}$ & $\mathrm{Y}$ & $\mathrm{Y}$ \\
Region & $\mathrm{N}$ & $\mathrm{Y}$ & $\mathrm{Y}$ & $\mathrm{Y}$ \\
Industry & $\mathrm{N}$ & $\mathrm{N}$ & $\mathrm{Y}$ & $\mathrm{Y}$ \\
Part-time & $\mathrm{N}$ & $\mathrm{N}$ & $\mathrm{Y}$ & $\mathrm{Y}$ \\
Firm size & $\mathrm{N}$ & $\mathrm{N}$ & $\mathrm{Y}$ & $\mathrm{Y}$ \\
Sector (public/private) & $\mathrm{N}$ & $\mathrm{N}$ & $\mathrm{Y}$ & $\mathrm{Y}$ \\
Occupation & $\mathrm{N}$ & $\mathrm{N}$ & $\mathrm{N}$ & $\mathrm{Y}$ \\
\hline R 2 & 0.246 & 0.315 & 0.513 & 0.591 \\
\hline Sample Size & 257 & 257 & 254 & 248 \\
\hline \hline
\end{tabular}

Notes: Heteroscedasticity robust standard errors in parentheses. Sample consists of employees of working age and excludes full-time students. The models include 3 marital status, 12 regional, 12 industrial, 3 firm size and 9 occupational dummies. 
Table 5

Earnings Equations for Other A8 Migrants to the UK

\begin{tabular}{lccrc}
\hline & $\mathbf{1}$ & $\mathbf{2}$ & $\mathbf{3}$ & $\mathbf{4}$ \\
\hline Years of education & $0.067(0.020)$ & $0.064(0.023)$ & $0.051(0.024)$ & $0.041(0.026)$ \\
Experience & $0.018(0.014)$ & $0.016(0.013)$ & $0.000(0.013)$ & $0.003(0.015)$ \\
Experience-squared/100 & $-0.031(0.035)$ & $-0.046(0.033)$ & $-0.017(0.031)$ & $-0.008(0.033)$ \\
$1980 s$ & $-0.189(0.228)$ & $-0.498(0.264)$ & $-0.170(0.327)$ & $-0.140(0.289)$ \\
$1990 s$ & $-0.275(0.244)$ & $-0.527(0.263)$ & $-0.212(0.356)$ & $-0.108(0.314)$ \\
2000-3 & $-0.628(0.222)$ & $-0.905(0.241)$ & $-0.250(0.327)$ & $-0.148(0.294)$ \\
Post-Enlargement & $-0.599(0.229)$ & $-0.927(0.247)$ & $-0.312(0.342)$ & $-0.203(0.306)$ \\
\hline Controls for: & & & & \\
Gender & $\mathrm{N}$ & $\mathrm{Y}$ & $\mathrm{Y}$ & $\mathrm{Y}$ \\
Marital Status & $\mathrm{N}$ & $\mathrm{Y}$ & $\mathrm{Y}$ & $\mathrm{Y}$ \\
Region & $\mathrm{N}$ & $\mathrm{Y}$ & $\mathrm{Y}$ & $\mathrm{Y}$ \\
Industry & $\mathrm{N}$ & $\mathrm{N}$ & $\mathrm{Y}$ & $\mathrm{Y}$ \\
Part-time & $\mathrm{N}$ & $\mathrm{N}$ & $\mathrm{Y}$ & $\mathrm{Y}$ \\
Firm size & $\mathrm{N}$ & $\mathrm{N}$ & $\mathrm{Y}$ & $\mathrm{Y}$ \\
Sector (public/private) & $\mathrm{N}$ & $\mathrm{N}$ & $\mathrm{Y}$ & $\mathrm{Y}$ \\
Occupation & $\mathrm{N}$ & $\mathrm{N}$ & $\mathrm{N}$ & $\mathrm{Y}$ \\
\hline R $^{2}$ & 0.201 & 0.287 & 0.437 & 177 \\
\hline Sample Size & 179 & 179 & 0.535 \\
\hline \hline
\end{tabular}

Note: Heteroscedasticity robust standard errors in parentheses. Sample consists of employees of working age and excludes full-time students. The models include 3 marital status, 12 regional, 13 industrial, 3 firm size and 9 occupational dummies. 
Table 6

Earnings Equations for Migrants to the UK

\begin{tabular}{|c|c|c|c|c|c|}
\hline & Poles & Other A8 & $\begin{array}{c}\text { Other } \\
\text { Europeans }\end{array}$ & $\begin{array}{c}\text { Eng. Speaking } \\
\text { Countries }\end{array}$ & Other Countries \\
\hline \multicolumn{6}{|l|}{ Specification 1} \\
\hline Years of education & $0.062(0.012)$ & $0.065(0.024)$ & $0.084(0.003)$ & $0.085(0.005)$ & $0.068(0.002)$ \\
\hline Experience & $0.016(0.012)$ & $0.023(0.012)$ & $0.039(0.003)$ & $0.044(0.004)$ & $0.024(0.002)$ \\
\hline Experience-squared/100 & $-0.045(0.034)$ & $-0.081(0.031)$ & $-0.079(0.006)$ & $-0.080(0.010)$ & $-0.055(0.005)$ \\
\hline Years since migration & $0.018(0.006)$ & $0.029(0.006)$ & $0.004(0.001)$ & $0.000(0.001)$ & $0.011(0.001)$ \\
\hline \multicolumn{6}{|l|}{ Specification 2} \\
\hline Years of education & $0.027(0.013)$ & $0.042(0.025)$ & $0.029(0.003)$ & $0.042(0.005)$ & $0.020(0.002)$ \\
\hline Experience & $0.012(0.008)$ & $0.004(0.015)$ & $0.023(0.002)$ & $0.030(0.004)$ & $0.014(0.002)$ \\
\hline Experience-squared/100 & $-0.042(0.023)$ & $-0.012(0.033)$ & $-0.045(0.005)$ & $-0.056(0.010)$ & $-0.034(0.004)$ \\
\hline Years since migration & $0.005(0.004)$ & $0.006(0.008)$ & $0.000(0.001)$ & $-0.001(0.001)$ & $0.004(0.001)$ \\
\hline \multicolumn{6}{|l|}{ Specification 1} \\
\hline Years of education & $0.051(0.013)$ & $0.078(0.029)$ & $0.094(0.004)$ & $0.088(0.006)$ & $0.064(0.004)$ \\
\hline Experience & $0.011(0.012)$ & $0.033(0.014)$ & $0.041(0.003)$ & $0.045(0.004)$ & $0.023(0.002)$ \\
\hline Experience-squared/100 & $-0.031(0.036)$ & $-0.113(0.039)$ & $-0.085(0.006)$ & $-0.081(0.011)$ & $-0.052(0.005)$ \\
\hline Years since migration & $0.001(0.014)$ & $0.056(0.023)$ & $0.011(0.002)$ & $0.003(0.004)$ & $0.008(0.002)$ \\
\hline Yrs since mig.* ${ }^{*}$ yrs of ed./100 & $0.142(0.121)$ & $-0.183(0.151)$ & $-0.055(0.017)$ & $-0.019(0.030)$ & $0.024(0.015)$ \\
\hline \multicolumn{6}{|l|}{ Specification 2} \\
\hline Years of education & $0.025(0.013)$ & $0.047(0.029)$ & $0.030(0.004)$ & $0.042(0.006)$ & $0.018(0.003)$ \\
\hline Experience & $0.010(0.009)$ & $0.008(0.017)$ & $0.023(0.003)$ & $0.030(0.004)$ & $0.014(0.002)$ \\
\hline Experience-squared/100 & $-0.039(0.028)$ & $-0.024(0.039)$ & $-0.046(0.005)$ & $-0.056(0.010)$ & $-0.033(0.004)$ \\
\hline Years since migration & $0.001(0.013)$ & $0.015(0.022)$ & $0.001(0.002)$ & $0.000(0.004)$ & $0.002(0.002)$ \\
\hline Yrs since mig.*yrs of ed./100 & $0.033(0.106)$ & $-0.062(0.136)$ & $-0.003(0.014)$ & $-0.004(0.026)$ & $0.012(0.012)$ \\
\hline $\mathrm{N}$ (Specification 1) & 257 & 179 & 3686 & 1755 & 6417 \\
\hline
\end{tabular}

Note: Heteroscedasticity robust standard errors in parentheses. Specification 1 also includes gender, marital status and region.

Specification 2 has additional controls for part-time, firm size, sector, industry and occupation. Sample consists of employees of working age and excludes full-time students. 
Table A1

Descriptive Statistics for Migrant Groups

\begin{tabular}{|c|c|c|c|}
\hline & $\begin{array}{c}\text { Post-Enlargement } \\
\text { Migrants }\end{array}$ & Poles & $\begin{array}{l}\text { Other A8 } \\
\text { Migrants }\end{array}$ \\
\hline Years of education & $13.928(2.966)$ & $13.960(2.708)$ & $13.192(2.724)$ \\
\hline Experience & $10.144(8.835)$ & $10.875(10.624)$ & $12.186(10.769)$ \\
\hline Poles & $0.254(0.435)$ & 1.000 & - \\
\hline Other A8 countries & $0.117(0.322)$ & - & 1.000 \\
\hline Other Europeans & $0.153(0.361)$ & - & - \\
\hline English speaking countries & $0.197(0.398)$ & - & - \\
\hline Other countries & $0.278(0.448)$ & 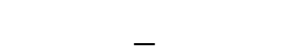 & _ \\
\hline Arrived before 1980 & - & $0.060(0.239)$ & $0.093(0.291)$ \\
\hline Arrived in the 1980s & - & $0.093(0.291)$ & $0.035(0.184)$ \\
\hline Arrived in the 1990s & - & $0.141(0.349)$ & $0.157(0.365)$ \\
\hline Arrived 2000-3 & & $0.165(0.372)$ & $0.355(0.480)$ \\
\hline Arrived after 2003 & 1.000 & $0.540(0.499)$ & $0.360(0.482)$ \\
\hline Male & $0.581(0.494)$ & $0.500(0.501)$ & $0.430(0.497)$ \\
\hline Married & $0.468(0.499)$ & $0.464(0.500)$ & $0.483(0.501)$ \\
\hline London & $0.246(0.431)$ & $0.238(0.427)$ & $0.308(0.463)$ \\
\hline East/South East & $0.223(0.417)$ & $0.246(0.432)$ & $0.262(0.441)$ \\
\hline Other UK & $0.530(0.500)$ & $0.516(0.508)$ & $0.430(0.497)$ \\
\hline \% in Production industries & $0.218(0.413)$ & $0.214(0.410)$ & $0.267(0.444)$ \\
\hline$\%$ in Construction industries & $0.034(0.182)$ & $0.040(0.197)$ & $0.052(0.223)$ \\
\hline \% in Retail/hospitality inds & $0.218(0.413)$ & $0.319(0.467)$ & $0.198(0.399)$ \\
\hline$\%$ in Other Services & $0.530(0.500)$ & $0.427(0.496)$ & $0.483(0.501)$ \\
\hline \% Managerial/Professional & $0.347(0.476)$ & $0.194(0.396)$ & $0.186(0.390)$ \\
\hline$\%$ in Intermediate occs & $0.152(0.359)$ & $0.177(0.383)$ & $0.215(0.412)$ \\
\hline$\%$ in Semi Routine occs & $0.248(0.432)$ & $0.306(0.462)$ & $0.209(0.408)$ \\
\hline \% in Routine occupations & $0.254(0.436)$ & $0.322(0.468)$ & $0.390(0.489)$ \\
\hline Part-time & $0.108(0.311)$ & $0.157(0.365)$ & $0.169(0.375)$ \\
\hline Public Sector & $0.134(0.342)$ & $0.097(0.296)$ & $0.151(0.359)$ \\
\hline Organisation size $<25$ & $0.295(0.457)$ & $0.387(0.488)$ & $0.372(0.485)$ \\
\hline Organisation size: 25-499 & $0.540(0.499)$ & $0.504(0.501)$ & $0.506(0.501)$ \\
\hline Organisation size: 500 \& over & $0.165(0.371)$ & $0.109(0.312)$ & $0.122(0.485)$ \\
\hline Job tenure: less than 3 months & $0.237(0.425)$ & $0.190(0.393)$ & $0.134(0.341)$ \\
\hline Job tenure: 3-6 months & $0.199(0.400)$ & $0.133(0.340)$ & $0.116(0.321)$ \\
\hline Job tenure: 6-12 months & $0.299(0.458)$ & $0.254(0.436)$ & $0.285(0.453)$ \\
\hline Job tenure: $1-2$ years & $0.182(0.386)$ & $0.189(0.393)$ & $0.198(0.399)$ \\
\hline Job tenure: 2-5 years & $0.040(0.196)$ & $0.109(0.312)$ & $0.169(0.375)$ \\
\hline Job tenure: over 5 years & $0.044(0.204)$ & $0.125(0.331)$ & $0.099(0.299)$ \\
\hline Sample Size & 528 & 248 & 172 \\
\hline
\end{tabular}

Notes: Descriptive statistics relate to specification (4). Standard deviations in parentheses. The descriptive statistics for the industrial and occupational dummies reported above are based on grouped categories, compared to those included in the econometric estimates. 